В связи с вопросом о художественной манере поэта (и, в частности, о его отношении к художественному «реализму») см. отдельную публикацию Р. Бобрыка ${ }^{9}$. В финале рецензируемой книги приведен довольно объемный индекс цитируемых произведений Херберта, что само по себе свидетельствует о представительности разбираемого исследователем массива текстов.

Сергей Анатольевич Шульи

\title{
Литература:
}

BOBRYK, R.: Koncept poezji i poety w wierszach Zbigniewa Herberta. Siedlce, 2017. BOBRYK, R.: Odrealniony realism: $O$ „Trzech studiach na temat realizmu” Zbigniewa Herberta. In: Slavica Tergestina, 2014-2015, vol. 16, s. 66-85.

Zbignev Cherbert. <http://vladivostok.com/Speaking_In_Tongues/herbert.htm>. [online]. [cit. 2. 3. 2019].

\section{Puškinova recepce na Slovensku (1988-2015) a její přesahy}

ELIÁŠ, A., KUSÁ, M., LUKÁČOVÁ, A.: A. S. Puškin na Slovensku (1988-2015). Bratislava: Univerzita Komenského v Bratislavě 2018. ISBN 978-80-233-4465-4.

Recepce literárních jevů se postupně stala slovenskou specialitou - pramenů této orientace je jistě více, ale své slovo tu nepochybně měl koryfej slovenské rusistiky a komparatistiky Dionýz Ďurišin (1929-1997). Ten poukázal na nezbytí alespoň nějaké formy pozitivní diskriminace tzv. malých literatur, $\mathrm{k}$ nimž i česká - poněkud v jiném gardu - také náleží. Recepce cizích jevů je pro takovou literaturu nesmírně důležitá z hlediska udržení co nejintezivnější estetické komunikace a pravda je, i když se to často popírá, že malé literatury spíše přijímají, zejména ve fázi svého novodobého konstituování nebo rekonstituování, než dávají, což není jen jejich problém estetický, umělecký, ale spíše vina okolností: co je malé, má oproti velkému většinou nevýhody, pokud nenajde nějaký asymetrický kompenzační model (což se do jisté míry podařilo literatuře polské, dílem i české). Ruská literatura hrála $\mathrm{v}$ utváření slovenského literárního prostředí klíčovou roli, řekl bych, že mnohem silnější než v českém, jež bylo i v 19. století orientováno na Západ a skrze jeho estetickou „mřižku“ přijímalo -

9 BOBRYK, R.: Odrealniony realism: $O$ „Trzech studiach na temat realizmu” Zbigniewa Herberta. In: Slavica Tergestina, 2014-2015, vol. 16, s. 66-85. 
ale převážně do určité doby - ruské impulsy - to se mělo změnit až od období moderny a hlavně po roce 1918. Již podíl ruštiny na utváření spisovné slovenštiny byl zásluhou slovenských rusofilů podstatný, a to zvláště od druhé poloviny 19. století, nicméně mezi velkými Rusy nemohl nezaujmout klíčové místo A. S. Puškin a ačkoliv se to ani v Rusku zpočátku nezdálo, musel $\mathrm{k}$ velikosti dozrát $\mathrm{v}$ očích kritiků i čtenářů: ve 3o. letech 19. století zdaleka nepatřil v Rusku k nejpopulárnějším autorům, věděl to a snažil se to změnit (desítky neúspěšných románových incipitů, odchod k novinařině a historii, zmnožení prózy, historické poémy, státotvorná Historie Pugačovovy vzpoury). Teprve později překonal např. Fadděje Bulgarina, svého úhlavního neprrítele, zásluhou přátel a hlavně kritické reflexe svého složitého díla a jeho uvedením do kontextu a do zahraničí, především do Francie (zásluhou I. S. Turgeněva). Stalo se to také na pozadí mezinárodní recepce dalších autorů, kteří se stali skutečně světovými, jako byli kromě samotného Ivana Turgeněva, jenž se o to zasloužil svou propagací, styky a životem v západní Evropě - Lev Tolstoj a Fjodor Dostojevskij, teprve později Nikolaj Gogol a další. Ruská literatura má stěžejní postavení ve vlivné knize Émila Hennequina Spisovatelé ve Francii zdomácnělí (vlastně „pofrancouzštělí) ${ }^{1}$, kterou k nám uvedl a přeložil F. X. Šalda roku 1896 - jako jediná tu má tři zástupce, ale Puškin mezi nimi není. U nás je alespoň jeho poezie reprezentativně zastoupena v antologii Františka Vymazala Slovanské poezije $(1874)^{2}$.

Spoluautoři př́tomné publikace se podíleli (z nich snad nejvíce Mária Kusá) - spolu s řadou jiných filologů - na zkoumání recepce cizích literatur na Slovensku v rámci různých projektů; oni sami pak zkoumali právě recepci ruské literatury a nyní se dostali až k její současné fázi. Na příkladu Puškina demonstrovali zajímavé vývojové peripetie jeho recepce a překládání, které reagovaly na společenskou poptávku, zejména v souvislosti s politickými událostmi (1945, 1948, 1968, 1989), jež nakonec vedly k radikálnímu poklesu zájmu o všechno ruské (prríčiny zde nebudeme uvádět, ale je jich více) a potom $k$ nové vlně zájmu, navíc podporovanému kvalitními překlady a kritickými reflexemi. I když uvedené časové rozpětí Puškinovy recepce na Slovensku

1 Původně HENNEQUIN, É.: Écrivains francisés. Études de ctitique scientifique. Dickens - Heine Tourguéneff - Poe - Dostoïevski - Tolstoï. Paris: Librairie Académique Didier, Paris 1889; český překlad ŠALDA, F. X.: Spisovatelé ve Francii zdomácnělí. Josef Pelcl, Praha 1896.

2 VYMAZAL, F.: Slovanská poezije. Výbor z národního a umělého básnictva slovanského $v$ českých překladech. I. svazek. Ruská poezie. Brno: Matice moravská, 1874. Puškinova tvorba se tu nachází na s. 87-133; kromě lyriky (mj. Zimní večer, Ančar, Husar, Utopenec, Běsi) je tu Pohádka o zlaté rybce (pův. O rybake i rybke), výsostně politicko-deklarativní Pomlouvačům Ruska, poémy Bratři loupežníci, Poltava a Jevgenij Oněgin (tak tu zní český titul), většinou v překladech V. Č. Bendla. Viz o tom naši studii POSPÍŠIL, I.: A. S. Puškin v antologii Františeka Vymazala „Slavjanskaja poezija“. In: Nižnij Novgorod: Boldinskije čtenija, Komitet po kul'ture Nižegorodskoj oblasti, Gosudarstvennyj literaturno-memorial'nyj i prirodnyj muzej-zapovednik A.S. Puškina „Boldino“, Nižegorodskij gosudarstvennyj universitet im. N. I. Lobačevskogo, 2007, s. 264-269. 
zahrnuje pouze necelé dva roky tzv. normalizačního, resp. postnormalizačního období, hodnocení recepční aktivity zasahuje někdy až do 7o. let 2o. století. Autoři byli ve svém zkoumání seriózní, obezřetní, důkladní - ve smyslu bibliografické akribie, kritické reflexe a dodržovali i audiatur et altera pars. Navíc pro Čechy dost sympatickým rysem je i poměrně systémové zření $\mathrm{k}$ českému kontextu. takže $\mathrm{v}$ knize o slovenské recepci Puškina najdeme vlastně i spodní proud recepce české nebo zdvojené kritické reflexe česko-slovensko-ruské. $\mathrm{V}$ úvodním slově autoři právem hrdě sumarizují, co v této věci slovenská rusistika udělala a čeho byli oni sami strůjci: je to řada knih mapujících ruskou literaturu i v její recepční fázi - na rozdíl od prostředí českého, jež doslova trpí nehledě na třeba i hluboké studie - notorickým nedostatkem takových syntetických kompendií, snad s výjimkou antikvované učebnice R. Parolka a J. Honzíka a knihy Hralovy, když pomineme některé menší počiny učebnicového, přehledového typu.

Vyzvednout třeba jak úvodní charakteristiku Puškinovy recepce v letech 1988-2015, tak druhou kapitolu věnovanou funkci překladů Puškina v slovenském kulturním prostoru. Objevují se tu jména těch, kteří se v nové době o recepci Puškina a překlady zasloužili (L’ubomír Feldek, Ján Štrasser, Ján Zambor), ale jsou tu i literárněkritické reflexe, zejména př́spěvky zvěčnělého A. Červeňáka, a také reakce české rusistiky. Zajímavé je posouzení čtyř překladů Evžena Oněgina. První pořídil Samuel Bodický (1850-1919) roku 190o, další Janko Jesenský (1874-1945) roku 1942, Ivan Kupec (původním př́ijmením Kunoš, 1922-1997) roku 1972 a Ján Štrasser (nar. 1946) roku 2002. Autoři tyto překlady zevrubně a se značnou empatií kriticky posuzují, přičemž nejlépe dopadá poslední překlad Jána Štrassera. Na Slovensku se stalo už jakýmsi literárním folklorem, že nejhůře naopak dopadá Ivan Kupec, dobově sice chválený, ale potom odsuzovaný, a to nejen ve spojitosti s některými lapsy, nepřesnostmi, ale také s jeho jakýmsi napojením na tzv. normalizaci, která se údajně na př̀kladu Oněgina projevila, možná také s jeho společenským angažmá. Tento postup, kdy se stalo jaksi nezbytné Kupce kritizovat, byt tu věcné důvody jsou, mě vždy trochu nastraží a stávám se opatrným. Už v porovnání s českou situací, kdy ne vše, co vyšlo nejnověji, musí být i nejlepší - a hlavně by tu k objektivnějšímu hodnocení měl být i větší časový odstup. Jakési aktualizační a zpřítomňovací tendence Oněgina z pera Ivana Kupce může připomenout český překlad Olgy Maškové. Českých překladů je o poznání více: Václav Čeněk Bendl (1860), Václav Alois Jung (1892), Josef Hora (1937), Olga Mašková (1966) a Milan Dvořák (1999); když pomineme antikvovaný překlad Bendlův a dobrý, leč také zastaralý Jungův, zůstává nám tzv. klasický Horův, generačně zaměřený překlad Maškové, jenž už dost vyčpěl, a Dvořákův, jenž přes veškerou snahu nepostihl některé podstatné aspekty, zejména lakonické sdělování emocí. ${ }^{3}$

3 Analýzu českých překladů E. O. provedl ve své disertaci, kterou později vydal knižně, Stanislav Rubáš (roč. 1974). Disertace se jmenovala Evžen Oněgin v českých překladech a byla obhájena roku 
Vynikající je kapitola o překladu povídky Metelice/Vánice (slovensky 6 variant názvu) doplněná v př́loze dvěma nejstaršími překlady do slovenštiny pod různými názvy. Velmi dobré je také pojednání o Slovanském muzeu A. S. Puškina v Brodzanech, tedy o peripetiích jeho vývoje. Brněnské rusisty naučil jezdit do Brodzan doc. Jaroslav Mandát: tehdy - roku 1973 - jsem tam byl poprvé, to ovšem ještě muzeum nebylo, pouze zdevastovaný „kaštiel“. Když muzeum vzniklo, jmenovalo se tuším Muzeum slovensko-ruských literárních vztahů, což působilo zvláštně, nebot hrabata Friesenhofové mluvili už kvůli rodině Puškinova vraha barona Georgese-Charlese de Heeckerena d'Anthès (1812-1895) francouzsky, snad také německy nebo rusky. Po roce 1989 byla jinak zajímavá expozice odideologizována, ale ani dnešní název se mi nejeví jako adekvátní. Roku 1991 jsem se tam zúčastnil konference o A. Solženicynovi. ${ }^{4}$ To místo je nicméně velmi významné, i když s Puškinem spojené jen nepř́mo, sestrami Natálie Kátou a hlavně Alexandrou, prý Puškinovou utajenou milenkou. Autorka kapitoly zmiňuje všechny ty, kteří se Brodzany a jejich spojením s př́ibuznými básníka zabývali, včetně A. Isačenka, L. Kiškina a N. Rajevského.

Nepostradatelnou součástí užitečné publikace, která zůstane jako trvalý dokument, je bibliografie výběrová (Puškin v slovenském tisku, 1988-2015), a to slovenské překlady včetně antologií a sborníků, literatura o Puškinovi a věci spojené s činností Slovanského muzea A. S. Puškina v Brodzanech.

Kniha jako celek je dalším stupínkem v poznávání recepce ruské literatury na Slovensku a svými přesahy demonstruje i řadu obecných vlastností recipovaného díla a recepčního prostředí.

Ivo Pospišil

\section{Literatura:}

ELIÁŠ, A., KUSÁ, M., LUKÁČOVÁ, A.: A. S. Puškin na Slovensku (1988-2015). Bratislava: Univerzita Komenského v Bratislavě 2018.

HENNEQUIN, É.: Écrivains francisés. Études de ctitique scientifique. Dickens - Heine Tourguéneff - Poe - Dostoïevski - Tolstoï. Paris: Librairie Académique Didier, Paris

2006; školitelem byl Milan Hrala (1931-2015), oponenty Oldřich Král (1930-2018) a Jiří Honzík (1924-2018). Knižní vydání RUBÁŠ, S.: Já píši Vám - Evžen Oněgin v českých překladech. Brno: HOST, 2009 (některá hodnocení jsou ovšem jednostranná a přiliš suverénní).

4 Viz sb. KOVAČIČOVÁ, O., ELIÁŠ, A.: A. I. Solženicyn v kontexte európskej literatúry. Zborník príspevkov zo sympózia o tvorbe A. I. Solženicyna. Bratislava Univerzita Komenského, 1992. 
1889; český překlad ŠALDA, F. X.: Spisovatelé ve Francii zdomácnělí. Josef Pelcl, Praha 1896.

KOVAČIČOVÁ, O., ELIÁŠ, A.: A. I. Solženicyn v kontexte európskej literatúry. Zborník príspevkov zo sympózia o tvorbe A. I. Solženicyna. Bratislava Univerzita Komenského, 1992.

은 POSPÍŠIL, I.: A.S. Puškin v antologii Františeka Vymazala „Slavjanskaja poezija“. In: Nižnij Novgorod: Boldinskije čtenija, Komitet po kul'ture Nižegorodskoj oblasti, Gosudarstvennyj literaturno-memorial'nyj i prirodnyj muzej-zapovednik A. S. Puškina „Boldino“, Nižegorodskij gosudarstvennyj universitet im. N. I. Lobačevskogo, 2007, s. 264-269.

RUBÁŠ, S.: Já píši Vám - Evžen Oněgin v českých překladech. Brno: HOST, 2009.

VYMAZAL, F.: Slovanská poezije. Výbor z národního a umělého básnictva slovanského $v$ českých překladech. I. svazek. Ruská poezie. Brno: Matice moravská, 1874. 